\title{
Netstøtte til undervisning i naturvidenskab
}

\author{
Hvad mener de studerende om netstøtte til kurser med \\ laboratoriearbejde og regneopgaver
}

\section{Jens Josephsen}

Lektor, lic.scient. Studieleder i kemi

Institut for biologi og kemi

Roskilde Universitetscenter

phjens@,ruc.dk

http://www.ruc.dk/inst1/

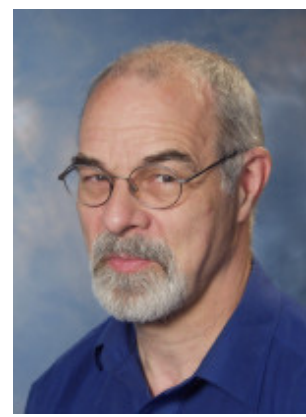

Jens Josephsen har lang tids erfaring med undervisning $i$ et tvoerfagligt naturvidenskabeligt miljø på indledende universitetsniveau og med kemiuddannelse fra det elementore til det avancerede. I de sidste 10 år har han interesseret sig for hvordan PC'er og internetadgang kan anvendes $i$ undervisningen og har bl.a. gennemført et par udviklingsprojekter inden for rammerne af DCN (Dansk Center for Naturvidenskabsdidaktik1998-2003) med IT i kemiundervisningen som tema. Projekterne har varet fulgt op af undersøgelser af de studerendes feed-back på sådanne elementer i undervisningen.

I et indledende kursus i uorganisk kemi for naturvidenskabelige bachelorstuderende ved RUC er der indført en række forskellige pædagogiske og administrative elementer, som nås via nettet. De studerendes feed-back herpå er undersøgt over nogle år. Selv om de indførte ressourcer hverken er særligt avancerede eller udnytter de sidste nye IT-værktøjer og platforme eller deres faciliteter, er de studerende ganske tilfredse med de faktiske hjælpemidler, som fungerer efter hensigten og er skræddersyede til de pågældende formål. Bortset fra et større arbejde i starten har dette netstøttede set-up også betydet en lettelse for underviseren.

\section{Undervisning i naturvidenskab og anvendelse af EDB}

I naturvidenskabelige fag er der tradition for meget lærerintensiv undervisning. Dette afspejles i budgetter, hvor der typisk arbejdes med en S/L-ratio for et naturvidenskabeligt fag som helhed på omkring 10 -15 (afhængigt af opgørelsesmetoden), medens der i de humanistiske og samfundsvidenskabelige fag typisk skal undervises mindst det dobbelte antal. Det kan have at gøre med at naturvidenskabelige fag er præget af et eller få, meget veludviklede og komplekse paradigmer, medens mange humanistiske fag er poly-paradigmatiske. I solide, naturvidenskabelige paradigmer vil anvisninger af rækkefølger og præsentationer på et passende niveau, der svarer til den lærendes øjeblikkelige kognitive niveau kræve megen tilrettelæggelse fra lærerens side. Det er en del af forklaringen. Men dele af de naturvidenskabelige fag er også sådan indrettede, at de mest effektivt indlæres i mesterlære situationer, dvs. ved at gøre som mester gør (som bl.a. omfatter: at gøre noget på en måde som mester har beskrevet det skal gøres). En del af disse "øvelser" indeholder omgang med farlige eller dyre og gerne langsommelige procedurer og teknikker, der måske oven i købet kræver erfaringsbaseret håndelag. Det gør, at vejledning på stedet er påkrævet i vidt omfang. Der vil typisk være mange spørgsmål at besvare i sådanne øvelsesseancer og nogle teknikker eller "tricks" skal demonstreres. Forklaringen på dette behov er ikke alene, at de studerende ikke har brugt 
den fornødne tid på at overskue hvad der - og nogle gange også hvordan det - skal gøres (det er nemlig også noget, der skal læres), men også at den kognitive belastning ofte er stor i skriftlige vejledninger.

Ifølge kognitiv belastningsteori vekselvirker særlige træk ved strukturen af information og den menneskelige kognitive arkitektur på en måde, der har stor indflydelse på, hvordan vi lærer og forstår. Nogle gange er vekselvirkningen med noget der skal læres så kraftig, at det ikke kan behandles i bevidstheden samtidigt med at det forstås; det skal først lagres i en skematisk form i langtidshukommelsen. (Pollock 2002). Fra en konstruktivistisk synsvinkel er den studerendes egen formulering af det opfattede en vigtig vej til at lære. På den baggrund må man formode, at læringssituationer med fordel kan tilrettelægges så de nødvendiggør den selvstændige formulering $\mathrm{i}$ en dialog med en medstuderende og med en lærer som konsulent. I dialogen ligger en nødvendig feed-back på, hvordan et formuleret udsagn i en anden persons øre lyder som et fornuftigt udsagn, der repræsenterer en indlæring. Med IKT er der potentielle muligheder til at tænke i forud programmeret feed-back i opgaver, som en oplagt måde at forsøge at forøge dialogaspektet i de studerendes samarbejde og derved stimulere konstruktionen af viden.

Inden for undervisning i naturvidenskabelige felter har der været en lang tradition for anvendelsen af IKT. Den oprindelige indgang var den regnekraft der ligger i EDB. Hovedsagen var da at kunne illustrere vigtige sammenhænge ved på kort tid at foretage mere komplicerede beregninger end tidligere. Her ligger fortsat den særlige nytte, som naturvidenskabelige erkendelsesprocesser kan drage af forskellige EDB-baserede værktøjer. De har det til fælles, at de leverer en respons på et givet input. Kvaliteten af denne feedback er ofte ganske afhængig af kvaliteten af inputtet.

Det gælder bl.a. programmer til:

1. Illustration af fænomener vha. billeder eller animationer (tegnefilm eller anden grafik) hvor tidslig eller rumlig udvikling er vigtig.

2. Demonstration af apparatur og metoder vha. videooptagelser og ledsagende indtalte forklaringer og tekst.

3. Statistisk behandling af data.

4. Databasesøgning med ekstraherings- og repræsentationsfaciliteter.

5. Test og træning af konkrete opgaver og eksempler.

6. Beregning af talværdier for en fysisk størrelse (en egenskab) i en matematisk formuleret model, herunder simulering af eksperimentelle situationer med måltal.

7. Simulering af mere sammenhængende kvalitative eksperimenter.

I den udstrækning softwaren findes (og har indbygget introduktion, instruktioner og hjælpefunktioner) kan man spørge sig om, hvor stort behovet er for undervisning. Spørgsmålet har en parallel til undervisningens rolle, når der benyttes lærebøger: svaret er af samme grund afhængigt af graden af det selvinstruktions-potentiale der findes i studerende og læremateriale. Erfaringen er, at undervisning kan gavne, om ikke af anden grund så ved at sætte scenen for en anledning for de studerende til at gøre noget bestemt, som de ellers næppe (i hvert fald ikke alle sammen) ville have fået gjort. Selvinstruktions-koefficienten er heller ikke lige høj for alle programmer, så en - i nogle tilfælde ganske - kort introduktion vil oftest være virkningsfuld. Hermed er sagt, at der er god mening i under alle omstændigheder at beskæftige sig med tilrettelæggelse af undervisningen og $i$ at placere anvendelsen af de pågældende programmer i en velovervejet sammenhæng med andre elementer. Mange af de anvendte (kommercielle) programmer har et utal af forskellige funktioner og alene at hitte rundt i disse 
- eller i dem der er relevante i den planlagte sammenhæng - kræver noget arbejde. Her er det også nyttigt med en lærer, som tilrettelægger og vejleder.

\section{Indførelse af flere IKT elementer i et kursus - et eksempel}

Over en årrække er der indført netstøtte til flere forskellige aspekter ved afviklingen af et kursus $i$ indledende uorganisk kemi for naturvidenskabelige bachelor-studerende på RUC, og IKT-ressourcerne har været udvalgt, sammensat og afpasset til de aktuelle formål

Til nogle formål findes anvendelige internetressourcer allerede. Arbejdet for læreren er her at vælge den ressource ud, som synes mest tilforladelig (internettet er ikke kvalitetscensureret) og synes at opfylde det aktuelle mål bedst muligt. I nogle tilfælde findes ressourcerne om et givet emne allerede samlet, og det er på en måde en censurering, når henvisninger til analoge kilder findes på en web-side, og de bedste synes at være valgt ud. Dette gælder oplysninger om håndtering af kemikalier og stoffer, som er et emne for undervisning $\mathrm{i}$ kemi. Dette vil blive eksemplificeret konkret. Ressourcens feedback har her karakter af et (opdateret) leksikalt svar på et konkret spørgsmål. De studerendes feedback afhænger af hvordan de ser adgangen til denne type oplysninger i en større sammenhæng.

Kommercielle programmer til afvikling af kurser via web-sider er heller ikke altid optimale. Dels er prisen høj, og de anskaffes derfor kun, når der er mange brugere (helst en hel institution), og dels skal de af den grund være generelle med en masse forskellige faciliteter, hvilket gør dem mindre elementære at bruge. Hjemmegjorte hjemmesider kan (i det mindste for en tid) være en løsning, der er et bedre alternativ end at have en meget dyr og indviklet hjemmeside, hvis faciliteter ikke bliver anvendt. Træk ved og krav til en sådan kursushjemmesides funktion vil også blive eksemplificeret ud fra de gjorte erfaringer (Kristensen og Josephsen 2002a). Hjemmesiden giver den type oplysninger som en (virtuel og opdateret) opslagstavle. De studerendes feedback er betinget af at de (bl.a. hjemmefra) kan finde de (pålidelige og komplette) oplysninger, som de skal bruge i forbindelse med kursusarbejdet.

Når det gælder træning i løsning af problemstillinger (ovenstående listes nr. 5) inden for en afgrænset del af et paradigme (hvordan fungerer det, der står i lærebogsafsnittet konkret, og hvordan gennemregnes eksempler eller hvilken forklaring skal anvendes?) findes der programmer, som stiller spørgsmål og registrerer et svar (så er det et testprogram) - eller præsenterer en besvarelse på en opgave (så er det et en slags forståelseshjælpeprogram). Det er imidlertid sparsomt, hvad der findes af kommercielle programmer af denne slags, som også er interaktive. Det interaktive skal her forstås som den egenskab, at programmet kan folde problemet ud og præsentere en række forskellige spor, der kan indgå i besvarelsen af spørgsmålet. Hvert enkelt spor er yderligere delt op i små skridt, hvor mere detaljerede og reformulerede spørgsmål skal bidrage til at de studerende selv tager det følgende lille skridt i besvarelsen. Til hvert lille skridt er der så hjælp at hente i form af henvisninger til mulige data eller begrebslige og teoretiske sammenhænge i matematisk formulerede modeller, og efterfølgende et ordentligt svar på delspørgsmålet. Som et eksempel vil et hjemmelavet interaktivt program, der også har været benyttet i den indledende kemiundervisning, blive omtalt suppleret med nogle yderligere iagttagelser end de oprindeligt gjorte (Kristensen og Josephsen 2002b). Programmets feedback er komplekst og forskelligartet og fremkommer på en måde, der afhænger af, hvordan de studerende griber sagen an. De studerendes tilbagemelding afhænger af, om de udnytter den dialogprægede opbygning af programmet.

Til andre formål findes der ikke-kommercielle undervisningsprogrammer, og hvor de findes, dækker de måske ikke undervisningens mål mht. niveau, vinkling, fokus og metode, eller også passer de ikke til de aktuelle studenternes typiske læringsstil. ( Kolb 1984; Riding \& 
Rayner 1998). Med kommercielle programmer er det endnu mere udtalt end hvad der gælder for lærebøger, hvor udenlandsk litteratur dominerer og herhjemme suppleres med lærerens noter og anden litteratur. Man må altså ofte ty til hjemmegjorte programmer for at kunne gøre netop det, man anser for virksomt i den aktuelle sammenhæng.

Der kan som i ovenstående opremsning skelnes mellem simuleringsprogrammer, hvor hovedpointen er at finde en kvantitativ konsekvens af en række forudsætninger i en model (nr. 6 på listen) og andre programmer (nr.7), hvor pointen er at tolke kvalitative resultater af kendte procedurer i forskellige specialtilfælde. Mens der faktisk er en del programmer af den første type, er der længere mellem den sidste type. Det er nærliggende at udvikle sådanne programmer selv. Det betyder også at de kan skræddersyes så pasformen bliver optimal i forhold til den givne undervisningssituation. Som sagt er sådanne simuleringsprogrammer sjældne, bl.a. fordi de er så arbejdskrævende at fremstille. Som et eksempel vil der blive beskrevet et skræddersyet interaktivt simuleringsprogram og de studerendes reaktioner herpå (Kristensen \& Josephsen 2002c, Josephsen \& Kristensen 2002, Josephsen \& Kristensen 2004). I det følgende beskrives de fire ressourcer:

\section{Internetressourcer: Sikkerhed i laboratoriet}

Kurset $\mathrm{i}$ indledende uorganisk kemi er stærkt præget af dets laboratoriearbejde. Ved hjælp af velbeskrevne simple procedurer og semi-mikro teknikker arbejder de studerende $\mathrm{i}$ hold med at påvise og kvantificere en række simple kemiske bestanddele, som de vil kunne møde i kemiog biologilaboratorier. Herved håndterer de også standard laboratoriereagenser og andre mere specielle stoffer, som de ligeledes let kan støde på i andet laboratoriearbejde.

Fremgangsmåderne benytter små mængder kemikalier og reagenser, og der anvises stinkskab, når det er relevant for sikkerheden i arbejdet. Der er således i kursets tilrettelæggelse tænkt på sikkerheden, men det er en selvstændig pointe, at de studerendes opmærksomhed bliver rettet mod dette aspekt af laboratoriearbejde generelt. Derfor er der indlagt et undervisningselement, hvori der indgår en litteraturundersøgelse af faremomenter og forsigtighedsregler for håndtering af forskellige stoffer, som de møder i kurset. En vigtig del af dette er at hente forskellige oplysninger fra nettet. Her er der et eksempel på, at der er samlet henvisninger til flere forskellige engelsksprogede kilder på nettet et enkelt sted. Da det gælder oplysninger om kemikaliers potentielt sundhedsskadelige egenskaber og rette håndtering og området oven $\mathrm{i}$ købet er statsligt reguleret, er der god grund have tillid til et sådant sted. Oplysninger herfra kan så sammenlignes med, hvad der findes på de dansksprogede kilder. Når det er særligt relevant at hente oplysninger over nettet, så er det ikke kun, at det er nemt og bekvemt, men også at de konsulterede databaser løbende bliver opdateret med den nyeste viden. I et felt, hvor toksikologiske undersøgelser til stadighed udvider vores viden, og hvor anvendelser af kemikalier bl.a. af den grund reguleres, er der behov for den nyeste information. Det kan kun rationelt foregå via en database der løbende bliver opdateret.

At lære disse databasers (ret elementære) organisering og indhold at kende, og at se at en sammenligning er relevant, kræver næsten ingen hjælp, og det er derfor nyttigt blot at have arbejdet lidt med dem. De studerende er generelt tilfredse med henvisningen til denne ressource, fordi den er (gratis og) let at gå til, og dens opdaterede, leksikale oplysninger er relevante i deres studium og i den senere anvendelse af deres fag.

\section{Hjemmesiden for et kursus}

Hjemmesiden for det samme kursus er opbygget for 5-6 år siden og har siden været brugt stort set uændret (se Figur 1). Det skyldes, at de studerendes evaluering af den faldt så positivt ud (Kristensen \& Josephsen 2002a). De efterfølgende år har der været samme gode respons, dog 
kun dokumenteret vha. spørgeskemaer. De studerende er tilsyneladende ganske tilfredse med opbygning og indhold m.v., og hver studerende er i gennemsnit på hjemmesiden to gange om ugen, mens kurset løber. Tilbage i 2002 hvor vi foruden spørgeskemaer brugte oplysninger fra interview af de studerende, lærte vi af de studerendes respons noget om træk ved "den gode hjemmeside". Det er klart, at undersøgelsen af de studerendes opfattelse og anvendelse af web-siderne naturligvis er knyttet til det pågældende kursus' web-sted, men de observerede forhold og slutninger kunne tyde på at have mere universel karakter.

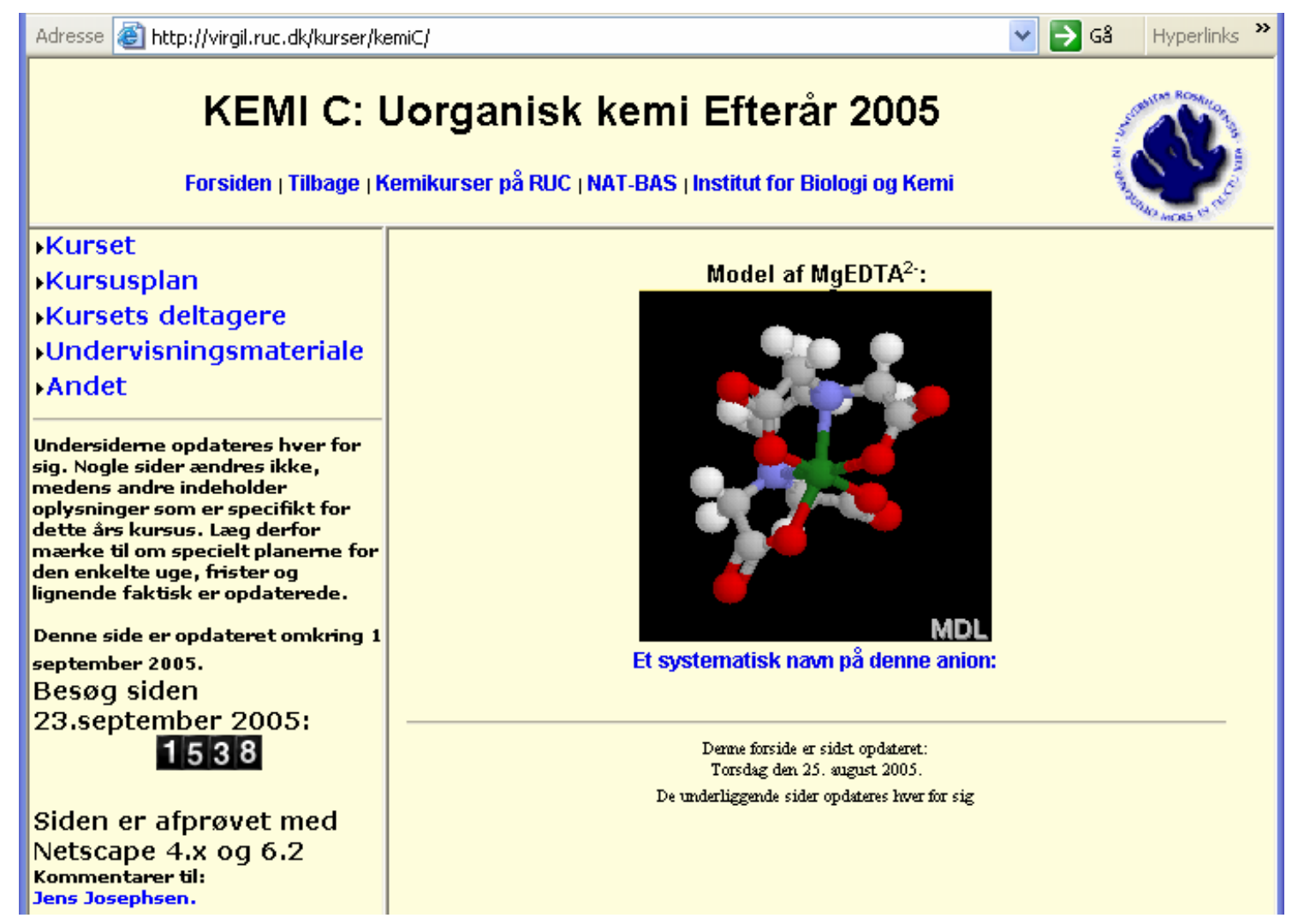

Fig.1. Kemi C hjemmesidens udseende pr. 1 oktober 2005. Den har voret stor set ucendret de sidste 4 år.

Ved design af en web-side til et lignende formål tør man på baggrund af disse første erfaringer anbefale følgende punkter overvejet med henblik på at skabe en brugbar studentervenlig hjemmeside. Lignende træk skal tilsvarende i det mindste findes i evt. kommercielle platforme til afvikling af kurser:

1. Hjemmesiden skal være klart og logisk opbygget med en overskuelig menu og undermenuer. Det skal være nemt og hurtigt at finde informationerne.

2. Den skal opdateres jævnligt, og i det hele taget holde hvad den lover.

3. Layoutet må meget gerne signalere dens indhold.

4. Den skal kun indeholde de nødvendige informationer og udvalgte, aktuelle henvisninger.

5. Den skal have opdateret aktivitetskalender og fungere som en virtuel opslagstavle.

6. Hjemmesiden må godt indeholde kursusmateriale (noter, forklaringer, faglige kommentarer). 
7. Den må også meget gerne indeholde (og løbende blive opdateret med) bearbejdninger af problemstillinger, der er behandlet i undervisningen; fx løsninger på opgaver, der er gennemgået, resuméer af studenter oplæg eller andre former for respons på stof, der arbejdes konkret med i kurset.

8. Chat rum faciliteter er unødvendige når de studerende har tilstedeværelsesundervisning og mødes flere gange om ugen.

Det er først og fremmest tilfredsstillende, at de studerende sætter pris på en hjemmeside med disse funktioner. Fra underviserens vinkel er det imidlertid værd at tilføje, at opdateringer efterhånden bliver rutine i forberedelsen til kurset og er en lille ulejlighed. Ænndringer i forholdt til det planlagte og offentliggjorte forløb eller aflysninger kan også sikkert meddeles via denne informationskilde. Desuden er det en lettelse ikke at skulle udlevere sedler med læselister eller andre typer af aftaler m.v. og huske at medbringe et rigtigt antal kopier. Det hele kommunikeres elektronisk, og hjemmesiden bliver alt $i$ alt en rationalisering af arbejdet med et kursus. Der er heller ingen studerende, der med rette kan komme og påstå, at de ikke kendte til noget - et velkendt trick blandt "efterladende" studenter - på dette kursus er der i hvert fald ikke nogen, der forsøger mere end én gang. Yderligere er det en meget effektiv måde at holde de studerende underrettet om deres status i kurset. I dette kursus er der en række opgaver og rapporter, som undervejs i kurset skal udarbejdes, afleveres og rettes af læreren for fejl og mangler. Godkendte opgaver og rapporter indgår således i, hvad der skal til for at have gennemført kurset. På hjemmesiden kan de studerende så følge med i, hvad der er godkendt (og hvad der mangler at bliver godkendt) på et givet tidspunkt. Dette aspekt af en hjemmeside er til gavn for både studerende og lærere.

\section{Regneopgaver}

I erkendelse af, at det er en generel intellektuel udfordring at lære at oversætte makroskopiske fremgangsmåder ( $\mathrm{fx}$ laboratorieforskrifter) til kemiske principper og fra makroskopiske observationer til kemiske konklusioner, er der ret meget fokus på dette aspekt $\mathrm{i}$ kurset. Laboratoriearbejdet og simuleringsprogrammet, der omtales nedenfor, er elementer i denne træning. En tredje ressource, der støtter dette formål, findes i form af "regneopgaver". Nogle af disse skriftlige opgaver er formuleret i et sprog, der læner sig op ad øvelsesvejledningens beskrivelse af laboratorieprocedurerne, og hvad man kan observere i laboratoriet ved at udføre simple eksperimenter. Det er en gammel erfaring, at denne type opgaver også udfordrer de studerende, og en del af kursustiden går med at "gennemregne" sådanne opgaver i plenum (med op til 60 studerende) i en dialogisk form enten med de studerende eller læreren som "kridtholder". Det er praksis på kurset, at opgaver, der løses fælles, efterfølgende bliver lagt i gennemregnet form på kursets hjemmeside. Det er de studerende meget tilfredse med.

I sådanne opgaveløsninger er der varierende grad af interaktivitet og feedback. For tiden består de fleste blot af en "løsning" (fremgangsmåde og resultat). Men der er et potentiale i interaktive kursusopgaver, som kan bearbejdes af de studerende over nettet. En sådan fungerer også i kurset (og kan nås on-line via http://virgil.ruc.dk/kurser/kemiopgaver/kol/indled.htm). Denne interaktivt programmerede opgave har til formål at skabe rammer for dialog mellem studerende indbyrdes, der arbejder i små hold med den, og mellem den studerende og programmet. Sådanne dialoger muliggør læringsprocesser, idet formuleringen med egne ord og feedback herpå fra en medstuderende (eller et program eller en lærer) er en vigtig faktor i konstruktion af viden.

Opgaveformuleringen er med vilje bred: "Hvad sker der, når man blander ..." (to kemikalier sammen). De studerende er ikke vant til at løse meget vagt formulerede opgaver fyldestgørende, selv om de godt kan præstere antydninger af svar her og der i den omfattende og modne løsning. Af denne grund er selve den brede formulering suppleret med nogle hjælpe- 
spørgsmål, som bringer de studerende rundt i det meste af opgavens besvarelse. Det har vist sig (Kristensen \& Josephsen 2002b), at det er muligt at få de studerende til at beskæftige sig mere med den dialogiske form i programmet, end hvis de blot fik det bredt formulerede spørgsmål, hvis besvarelse kræver et større overblik end de besidder i et indledende kursus. Programmet er opbygget med gradvise udfoldninger af problemet, idet det tilbyder og minder om nogle af fagets abstrakte kategorier, som kan benyttes til at stille sig selv spørgsmål og lede efter et svar. Problemet bliver så at sige brudt ned i bidder, som hver for sig er lettere at overskue og angribe end hele problemet på en gang. Denne udfoldning og detaljering sker i adskillige trin, så bidderne bliver så små, at det enkelte svar stiller meget få krav om viden. I sidste led er svaret givet (et beregnet tal eller et kvalitativt svar på en detalje formuleret $\mathrm{i}$ kemisk fagsprog). Ved løsningen af småbidderne skal der ofte benyttes data. Derfor har programmet også indbygget tabeller og andre oplysninger, som kan benyttes i arbejdet med problemet. Det er ikke kun relevante oplysninger der findes i tabellerne, men der er indbygget en responsfunktion i programmet: når den studerende har valgt en tabelværdi ledsages den af en forklarende kommentar, om den udvalgte faktuelle oplysning er relevant eller ej for løsningen af det aktuelle delspørgsmål. På sådanne måder fungerer programmet som den tålmodige vejleder, der ikke fungerer ved blot at vise, hvordan man løser et problem fra A til Z, men på konsulentbasis står til rådighed så længe det skal være med at give en lille smule hjælp ad gangen (ofte i form af mindre delspørgsmål) på de rigtige stadier i processen, så den studerende selv kan komme videre. Programmet er tidsmæssigt så tålmodigt som de studerende beder om, og dets feedback bliver derfor individuelt tilpasset. Nogle studerende bruger hjælpefunktionerne meget, medens andre har et større overblik og kan komme mere direkte igennem ved meget mindre hjælp.

De studerendes evaluering af programmet anerkender nytten af denne type programmer. En indirekte feedback på programmets anvendelighed er kommet fra et hold studerende, som skulle aflevere besvarelser af de omtalte hjælpespørgsmål. Det viste sig, at de studerende, der faktisk havde arbejdet med spørgsmålene ved hjælp af programmet, afleverede meget bedre besvarelser end de studerende, der blot havde besvaret de samme spørgsmål uden at anvende programmet.

\section{Et skræddersyet simuleringsprogram}

Halvdelen af undervisningstiden i kurset tilbringes i laboratoriet. Her er der nogle få større, sammenhængende øvelser. Øvelserne indeholder bl.a. kvalitativ analyse. Mestring af denne kvalitative dimension forudsætter, at den studerende (efterhånden) er i stand til at udføre en række bestemte (og anviste) kemiske operationer på en prøve, hvis indhold de ikke kender. Ud fra den måde hvorpå prøven reagerer - de studerende skal altså iagttage - skal de så slutte noget om sammensætningen af prøven. Her er det naturen, der giver tilbagemelding på en påvirkning, og en del af opgaven er at tolke denne feedback. Det involverer, at de studerende bliver i stand til at oversætte frem og tilbage mellem de makroskopiske og sub-mikroskopiske niveauer i beskrivelsen af kemiske reaktioner, dvs.

1. at oversætte den udførte kemiske operation ( $\mathrm{fx}$ "tilsæt dråbevis kaliumpermanganat til blivende rødfarvning, og derefter et par dråber toluen") via formålet med operationen til formler og viden om partiklernes egenskaber i stoffet (i eksemplet; kaliumpermanganat),

2. huske stoffernes ( $\mathrm{fx}$ toluens) i denne sammenhæng relevante egenskaber,

3. derefter at kende til de forskellige udfald af operationen i kemiske termer i form af kemiske formler og reaktionsligninger,

4. derefter hvordan disse forskellige udfald kan manifestere sig i reagensglasset, så man kan iagttage det, 
5. at iagttage udfaldet af operationen korrekt og afgøre hvilket aktuelt udfald der var af operationen,

6. at slutte tilbage om hvilke konsekvenser udfaldet af operationen har for relevante kemiske egenskaber af prøven og derved hvilken komponent i prøven disse slutninger peger på,

7. og slutteligt at kombinere tolkningen af resultatet af en række af sådanne operationer med henblik på afgøre prøvens kvalitative sammensætning.

Til en af disse øvelser er der udviklet et simuleringsprogram (som kan nås online via http://virgil.ruc.dk/kurser/kemiopgaver/KCO2/). Det er et eksempel på et kognitivt redskab (Lajoie), som kan understøtte de studerende i at løse en opgave med de ovennævnte kognitive udfordringer uden også at skulle bruge laboratorietid og indlæringspotentiale på at udføre eksperimenterne i virkeligheden (det skal nemlig også læres).

Da programmet kan nås via nettet, er det meningen, at de studerende også kan arbejde med læringsindholdet i disse laboratorieøvelser derhjemme (dvs. uden for laboratoriet) på anden måde, end ved at læse og memorere. Det er designet, så det minder meget om laboratoriumøvelserne, og teksten er affattet lige som i den omfattende øvelsesvejledning, ligesom billeder er stiliseringer af de simple laboratorieøvelser. Indledningssiden er afbildet i figur 2.

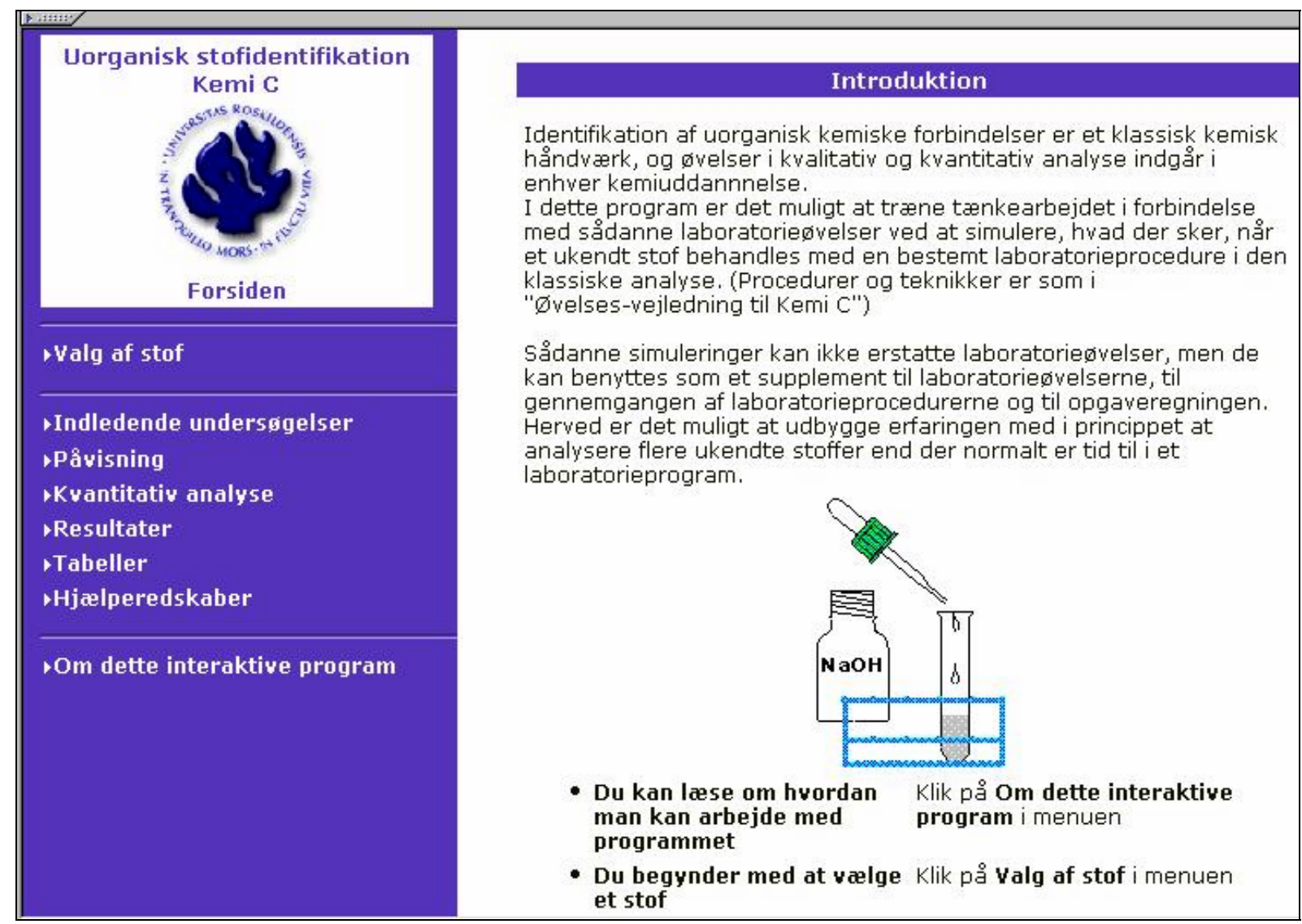

Figur 2. Indledningssiden i simuleringsprogrammet.

Der er en folde-ud menu i venstre side og med højre side som område, hvor resultatet af de mulige valg i menuen kan iagttages (se figur 3 og 4), hvor der efter valget af "Indledende undersøgelser" er valgt "Mål pH med pH-papir".

Som det ses, afkræves man derefter en simpel beskrivelse af denne måling, og programmet leverer herefter respons, dels i form af en be- (eller af-) kræftelse, og dels i form af et spørgsmål om, hvordan det kan tolkes. Der er også henvisninger til tabeller (Tabeller i menuen til 
venstre) med tabelværdier, som kan bruges i en sådan tolkning. Efter de "Indledende undersøgelser" foretages "Påvisning" efter en plan der afhænger af og skal koordineres med resultaterne fra "Indledende undersøgelser" og dernæst er der en "Kvantitativ analyse" at foretage.

I kursustiden introduceres de studerende til programmet og de bliver bedt om at arbejde $\mathrm{i}$ hold på to med det udtrykkelige formål at sikre en eksplicit dialog om hvilken rækkefølge de virtuelle laboratorieeksperimenter skal udføres og hvordan det enkelte eksperiment skal tolkes. Ud fra en konstruktivistisk synsvinkel vil dialogen nemlig være et stærkt middel i læreprocessen.

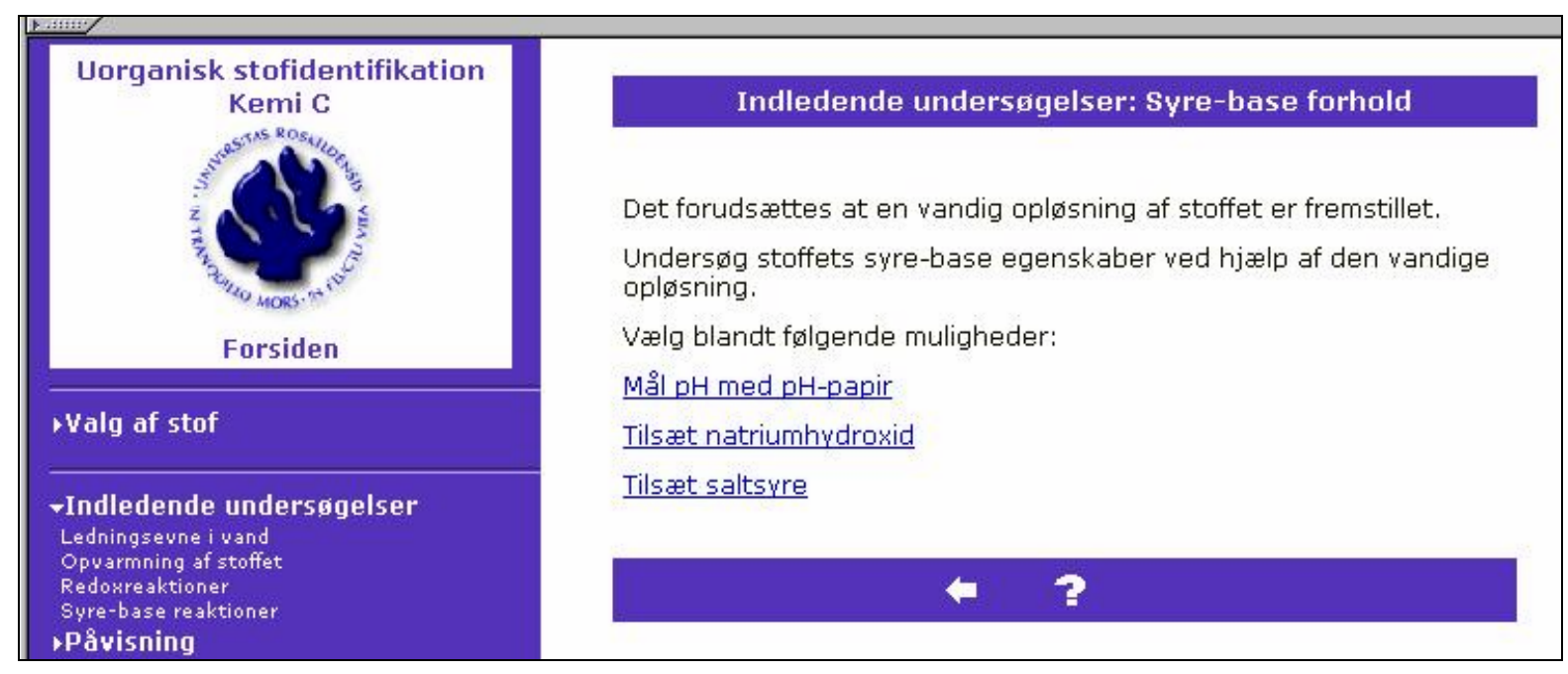

Figur 3. Efter valget mellem indledende undersøgelser (menu) skal man volge videre mellem tre forskellige småeksperimenter.

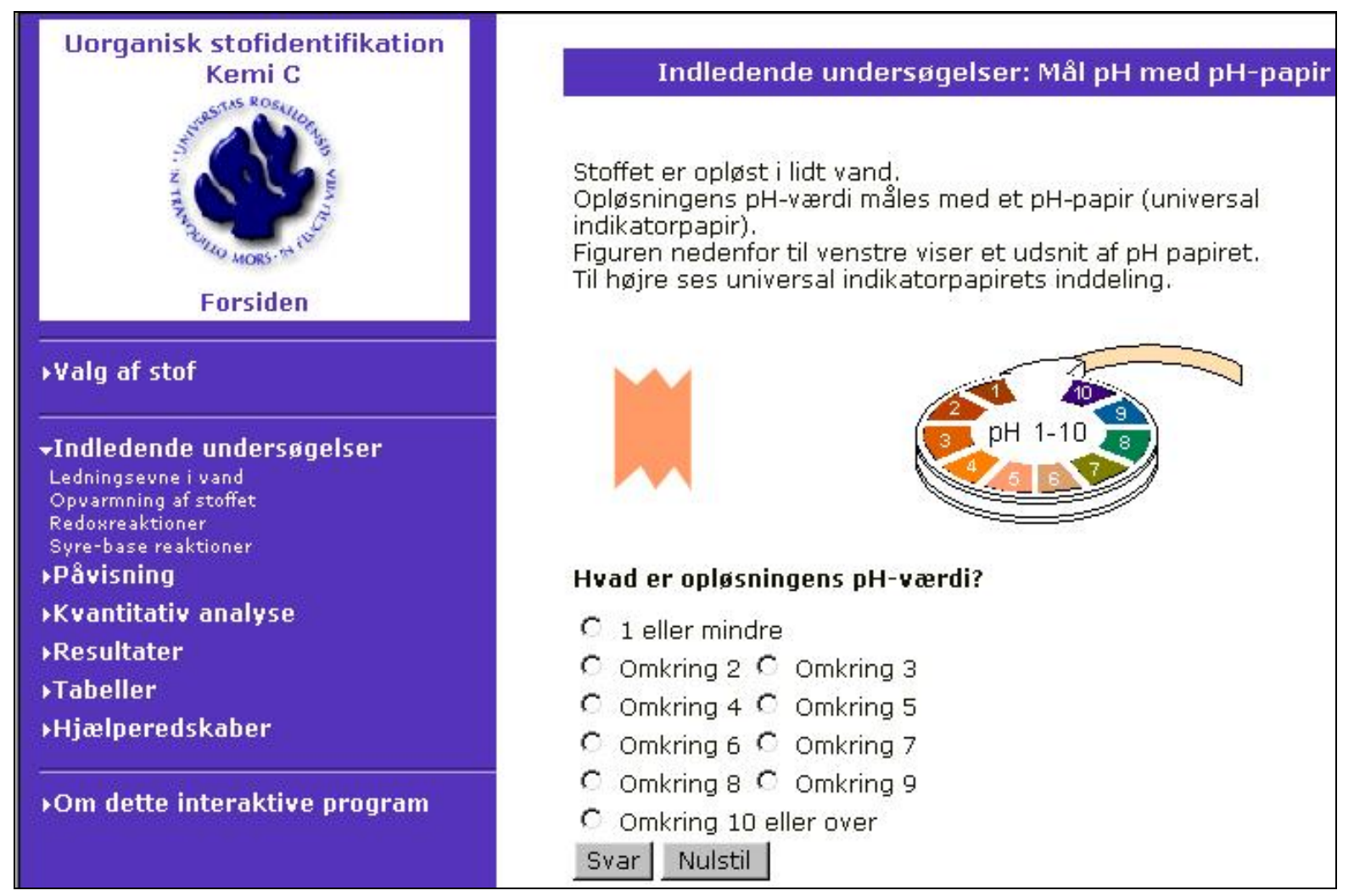

Figur 4. Valges den første mulighed jf. figur3 giver programmet som tilbagemelding en relativt naturtro reprcesentation af resultatet af eksperimentet. 
Tilbagemeldingen på arbejdet med programmet har været ret positive (Kristensen \& Josephsen 2002c, Josephsen og Kristensen 2002, 2004), og udsagn fra de studerende bekræfter, at programmets formål - at støtte de studerendes tænkeprocesser i den aktuelle sammenhæng er opfyldt. I laboratoriet er meget af de studerendes intellektuelle opmærksomhed rettet mod at udføre eksperimenterne ordentligt efter en beskrivelse, som de ikke er fuldt fortrolige med. I simuleringsprogrammet er der intet håndværksmæssigt problem og detaljer i proceduren (fx hvor mange dråber, eller hvor lang tid skal det stå og varme...) skal man ikke bekymre sig om. Det giver plads til at tænke over principper frem for fremgangsmåde. Som en af de studerende sagde: I laboratoriet kan man let glemme princippet bag eksperimentet. Man koncentrerer sig om at følge proceduren rigtigt. Her [i simuleringsprogrammet] .... kan man koncentrere sig om, hvad der sker.

Et vigtigt forhold ved laboratorieundervisning er den begrænsede tid, der er til rådighed. En kvalitet ved programmet er, at det i praksis udvider tiden, hvor de studerende kan få laboratorielignende erfaring. Det gælder den del af erfaringen, der knytter sig til observation og tolkning af eksperimenter, som man har nogen procedurel erfaring med fra det rigtige laboratorium. Der er altså tale om et voerdifuldt supplement og ikke en erstatning af laboratoriumarbejdet, understreger de studerende (uopfordret) i deres mundtlige og skriftlige respons. Mange studerende finder endvidere simuleringsprogrammet motiverende. Programmet fungerer m.a.o. i overensstemmelse med hensigten. De studerende har efter intensionen også nytte af at arbejde i hold. Som en af de studerende sagde "Vi taler om hvorfor vi udfører det ene eller det andet [eksperiment i simuleringen] og så bliver man mere bevidst om hvorforman argumenterer frem for bare at prøve" (min understregning). Pointen med den gensidige feedback mellem de studerende i samarbejdet med simuleringsprogrammet anerkendes altså af de studerende i deres evaluering af programmet.

Erfaringen er at skræddersyningen med indbyggede feedback-elementer til det præcise undervisningsforløb er nødvendig og at et sådant simuleringsprogram af laboratorieøvelser kan bidrage til at udvide de studerendes erfaringer med kemiske forbindelsers egenskaber. Det fungerer tillige som et alternativt tilbud til dem der har vanskeligere ved nogle af de andre undervisningsmidler og har en anden læringsstil (Kolb 1984, Riding \& Rayner 1998).

\section{Er det umagen værd?}

I det indledende kursus i uorganisk kemi ved RUC benyttes der en række forskelligartede internetbaserede hjælpemidler, der hver på sin måde giver tilbagemeldinger ved brugen af dem, til administrative og pædagogiske formål. Det krævede en del tid at indarbejde og tilpasse de eksisterende ressourcer og udvikle nye, men det betyder forbedringer og rationaliseringer, som også de studerende sætter pris på. Det bliver kursushjemmesiden, der er den samlende faktor, hvorfra alle relevante informationer kan nås, og hvor (henvisninger til) de øvrige netbaserede ressourcer findes. Det basalt vigtige er at holde hjemmesiden overskuelig og opdateret. For underviseren er det en lettelse, fordi erfaringerne fra sidste år er samlet og blot skal fornyes. Og når det hele ser velorganiseret ud for de studerende, er hjemmesiden en acceptabel henvisningsinstans, hvor man søger information frem for at spørge. De andre interaktive undervisningsressourcer er tilsyneladende værdifulde, bl.a. fordi de er skræddersyet til formålet med indbyggede feedback-funktioner, der giver forbedrede mulighed for at studere i et individuelt tempo. 


\section{Litteratur}

Josephsen, J. and A. Kosminska Kristensen (2002). Simulation of classical inorganic analysis on-line - what do the students think? Paper presented at the Variety in Chemistry Teaching Meeting, Keele University.

Josephsen, J.and A. Kosminska Kristensen (2004). Simulation of classical inorganic analysis on-line - how do the students react? In: Proceedings from the 7th ECRICE, University of Ljubljana. 2004. 158-168.

Kristensen, A. Kosminska \& Jens Josephsen (2002a). De studerendes anvendelse af kursushjemmesider. Kemi C 2001 som eksempel. CNCL Occasional paper 1.6/2002, Roskilde Universitetscenter 2002. Online: http://www.cncl.ruc.dk/pub/OP-1_6.pdf (downloaded 12.6.06)

Kristensen, A. Kosminska \& J. Josephsen (2002b). Hvordan reagerer førsteårsstuderende på et interaktivt computermedieret undervisningsprogram i kemi? CNCL Occasional paper 1.4/2002, Roskilde Universitetscenter 2002. Online: http://www.cncl.ruc.dk/pub/OP-1_4.pdf (downloaded 12.6.06)

Kristensen, A. Kosminska \& J. Josephsen (2002c). Hvad er de studerendes respons på et interaktivt simuleringsprogram i uorganisk kemi? CNCL Occasional paper 1.5/2002, Roskilde Universitetscenter 2002. Online: http://www.cncl.ruc.dk/pub/OP-1_5.pdf (downloaded 12.6.06)

Kolb, D. (1984). Experiential Learning. Prentice Hall..

Lajoie, S. P. (1993). Computer Environments as Cognitive Tools for Enhancing Learning. In: Lajoie, S.P. \& Derry, S.J. (eds.), Computers as Cognitive Tools. New Jersey: Lawrence Erlbaum Hillsdale. pp 261-288

Pollock, E., P. Chandler \& J. Sweller (2002). Assimilating complex information. Learning and Instruction 12 (2002). pp 61-86

Riding, R. \& S. Rayner (1998). Cognitive styles and Learning Strategies. Understanding Style Differences in Learning and Behaviour. David Fulton Publishers, Ltd.. 